\title{
KESULITAN GURU DALAM PENGEMBANGAN KETERAMPILAN BERPIKIR TINGKAT TINGGI SISWA DALAM PEMBELAJARAN BIOLOGI KELAS XII DI SMA NEGERI 2 GOWA
}

\author{
Nurhayani \\ Fakultas Tarbiyah dan Keguruan, UIN Alauddin Makassar \\ Kampus II Jalan H. M Yasin Limpo Nomor 36 Samata-Gowa \\ Sulawesi Selatan 92118, Telepon (Hp): 081212937556 \\ E-mail: nurhayaniani027@gmail.com \\ St. Syamsudduha \\ Fakultas Tarbiyah dan Keguruan, UIN Alauddin Makassar \\ Kampus II Jalan H. M Yasin Limpo Nomor 36 Samata-Gowa \\ Sulawesi Selatan 92118, Telepon (Hp): 081354634497 \\ E-mail: s.syamsudduha@gmail.com \\ Ahmad Afiif \\ Fakultas Tarbiyah dan Keguruan, UIN Alauddin Makassar \\ Kampus II Jalan H. M Yasin Limpo Nomor 36 Samata-Gowa \\ Sulawesi Selatan 92118, Telepon (Hp): 081341767665 \\ E-mail:ahmad.afiif@uin-alauddin.ac.id
}

\begin{abstract}
Abstrak
Penelitian ini bertujuan untuk mengetahui keterampilan berpikir tingkat tinggi siswa, mengetahui kesulitan yang dihadapi guru dan mengetahui solusi yang ditempuh dalam mengatasi kesulitan guru dalam mengembangkan keterampilan berpikir tingkat tinggi siswa di kelas XII di SMA Negeri 2 Gowa. Jenis penelitian yang digunakan adalah penelitian deskriptif kualitatif. Sampel purposif dalam penelitian ini adalah 3 guru biologi dan 67 siswa kelas XII IPA di sekolah SMA Negeri 2 Gowa. Instrumen penelitian yang digunakan dalam pengumpulan data dibagi atas 2 yaitu instrumen butir tes untuk kemampuan berpikir tingkat tinggi dan pedoman wawancara untuk mengetahui kesulitan dan solusi yang ditempuh untuk mengatasi kesulitann guru. Data yang diperoleh kemudian dianalisis dengan mereduksi, menyimpulkan dan menampilkan data. Berdasarkan data yang diperoleh dapat diketahui bahwa kemampuan berpikir tingkat tinggi siswa yaitu tergolong rendah. Kesulitan yang dihadapi oleh guru diantaranya adalah guru sulit mengatasi kemampuan siswa yang berbeda-beda, kurang mampu dalam menentukan metode dan model pembelajaran yang tepat, kurang memahami mengenai berpikir tingkat tinggi, membuat siswa merasa tertarik dalam merespon
\end{abstract}


apersepsi yang diberikan, kurang mampu menyesuaikan antara soal dengan kata kerja operasional, dan belum mampu mengatasi siswa yang mempunyai perbedaaan cara untuk menunjukkan kemampuannya dalam berpikir. Sedangkan solusi yang dapat ditempuh untuk mengatasi kesulitan guru dalam pembelajaran yaitu melakukan kegiatan pembelajaran secara berkelompok kepada siswa, diadakan pelatihan mengenai pengembangan keterampilan berpikir tingkat tinggi siswa, melakukan kegiatan apersepsi dengan gaya yang berbeda dengan biasanya, belajar untuk meningkatkan kapasitas yang diperlukan dalam proses pembelajaran, lebih banyak membaca referensi terkait bagaimana cara membuat tes, mengakumulasikan nilai yang diperoleh siswa, belajar untuk membuat instrumen penilaian.

Kata Kunci: Kesulitan Guru, Keterampilan berpikir, Berpikir Tingkat Tinggi

\begin{abstract}
This study aims to determine students' higher order thinking skills, know the difficulties faced by the teachers and find out the solution adopted in overcoming the difficulties of teachers in developing higher level thinking skills in class XII student at SMAN 2 Gowa. This type of research is descriptive qualitative research. Purposive sample in this study is three biology teachers and 67 students of class XII in school SMAN 2 Gowa. The research instruments used in data collection is divided into two, namely the instrument test items for high-level thinking skills and interview guides to know the difficulties and solutions adopted to overcome teachers difficulties. The data obtained and analyzed by reducing, summarize and display data. Based on the data obtained can be seen that the high-level thinking skills of students is relatively low. The difficulties encountered by teachers include teacher is difficult to overcome the ability of students of different, less able to determine methods and appropriate learning models, lack of understanding as to think critically, make students feel interested in responding apersepsi given, less able to adjust between about with said operational work, and have not been able to overcome the differences in the way students have to demonstrate their ability to think. While the solutions that can be taken to overcome the difficulties of teachers in the learning that is doing the learning activities in groups to the students, held training on the development of thinking skills of a high level of students, conducting apersepsi in a style different from the usual, learning to build the necessary capacities in the learning process, more reading related references how to make the test, accumulating a value obtained by students, learning to make the assessment instruments.
\end{abstract}

Keywords: Difficulty Master, Thinking skill, Higher-Order Thinking 


\section{PENDAHULUAN}

Pendidikan adalah proses transfer ilmu pengetahuan antara guru dan siswa. Guru menjadi faktor yang menentukan mutu pendidikan karena guru berhadapan langsung dengan siswa dalam proses pembelajaran di kelas. Mutu dan kepribadian peserta didik terbentuk di tangan guru, oleh karena itu, diperlukan juga seorang guru sebagai sosok kurikulum berjalan. Sebaik apapun kurikulum dan sistem pendidikan yang ada semuanya akan sia-sia tanpa didukung oleh kemampuan guru. Guru yang berkompeten dan bertanggung jawab akan mengawal perkembangan peserta didik sampai suatu titik maksimal. Tujuan akhir seluruh proses pendampingan guru adalah tumbuhmya pribadi yang dewasa.

Guru merupakan penentu dalam kualitas siswa, karena guru seringkali mengalami tingkat kesulitan tertentu dalam menfasilitasi siswa untuk mencapai kompetensi tertentu. Faktor-faktor yang menyebabkan terjadinya permasalahan dalam dunia pendidikan bukan hanya disebabkan oleh guru tetapi sarana-prasarana dan siswa, karena ketiga komponen tersebut sangat erat kaitannya untuk menunjang kemajuan dalam dunia pendidikan. Mengatasi permasalahan di kelas setiap guru itu berbeda sehingga berbagai macam strategi yang dikembangkan orang lain tidak dapat dipakai oleh semua guru. Perbedaan setiap guru untuk mengatasi permasalahan di kelasitu berbeda karenakan karakteristik masing-masing anak yang tergabung dalam rombongan belajar sangat spesifik sehingga setiap guru juga mempunyai strategi dalam mengatasi permasalahan di kelasnya (Rahman, 2015: 9).

Pembelajaran sains memiliki karakteristik untuk melibatkan siswa secara aktif, mampu bekerja sama dan menekankan hasil atau kompetensi akademik siswa. Peranan guru dalam proses pembelajaran lebih sebagai fasilitator dalam keberhasilan prestasi belajar siswa. Pembelajaran sains yang efektif memiliki tujuan untuk membantu siswa lebih mengembangkan keterampilan berpikir tingkat tinggi mereka terutama dalam berpikir kritis dan kreatif, kebebasan dalam berpikir, membangun penguasaan konsep esensial, mampu menyampaikan pendapat serta bentuk-bentuk dasar berfikir saintifik, membangun kepercayaan diri dalam memcahkan masalah atau pertanyaan yang diberikan serta menyelesaikannya atau mencari pemecahannya (Khoerunisa, 2013: 1).

Proses pembelajaran sains membutuhkan kemampuan berpikir tingkat tinggi siswa. Dengan berpikir tingkat tinggi siswa akan menggunakan potensi pikiran mereka secara maksimal untuk memecahkan suatu permasalahan. Berpikir tingkat tinggi juga diperlukan dalam meningkatkan keterampilan berbahasa dengan baik dan menganalisis. Kemampuannya dalam berpikir tingkat tinggi siswa juga mampu mengembangkan kreativitas mereka dalam proses pembelajaran. Selain itu, berpikir tingkat tinggi juga sangat penting untuk membiasakan diri siswa untuk berpikir.

Berpikir tingkat tinggi merupakan operasi kognitif yang banyak dibutuhkan pada proses-proses berpikir yang terjadi dalam shorterm memory. Jika dikaitkan dengan taksonomi Bloom, berpikir tingkat tinggi meliputi evaluasi, sintesis, dan analisis (Zannah, 2013: 32). Kemampuan berpikir tingkat tinggi sangat dibutuhkan dalam 
pembelajaran sains dimana guru berperan aktif dalam mengembangkan keterampilan berpikir siswa.

Berdasarkan penelitian awal melalui wawancara dengan salah seorang guru biologi yang bernama Ibu Ratna, S.Pd.pada hari Jum'at 21 Oktober 2016 di SMA Negeri 2 Gowa disimpulkan, beliau belum memahami secara betul mengenai apa itu pendekatan ilmiah (scientific approach). Pada saat mengajar, guru masih banyak menggunakan metode pembelajaran konvensional, menjelaskan setiap poin-poin materi pembelajaran, sementara siswa hanya mendengar dan mencatat materi yang diberikan. Dengan keadaan seperti ini, proses pembelajaran masih berpusat pada guru dan siswa pastinya tidak akan mengalami peningkatan selama proses pembelajaran berlangsung. Selain metode pembelajaran yang digunakan kurang inovatif, guru hanya berbekal buku siswa saja yang disediakan di sekolahdan tidak menggunakan media pembelajaran yang menarik dan tidak bervariasi. Selain itu, guru kurang berinovatif dalam proses pembelajaran, melihat lingkungan sekitar sekolah yang dapat dijadikan sebagai sarana atau media. Dengan kondisi seperti ini pastinya membuat seorang guru akan kesulitan dalammengembangkan kemampuan berpikir tingkat tinggi siswanya dalam proses pembelajaran.

Penelitian ini diharapkan mampu memberikan manfaat (1) Untuk guru diharapkan dapat menjadi salah satu acuan guru dalam menerapkan sistem pembelajaran untuk meningkatkan kemampuan berpikir tingkat tinggi siswa pada pembelajaran biologi, (2) untuk siswa diharapkan penelitian ini mampu meningkatkan kemampuan berpikir tingkat tinggi siswa yang terkait dengan mata pelajaran biologi, (3) untuk peneliti selanjutnya penelitian ini diharapkan dapat menjadi informasi awal bagi peneliti yang akan mengkaji tentang pengembangan keterampilan berpikir tingkat tinggi.

\section{Guru}

Guru dalam kamus besar bahasa Indonesia memiliki arti orang yang pekerjaannya, (mata pencahariannya, profesinya) mengajar. Guru adalah orang yang melakukan kegiatan dalam bidang mengajar. Setiap guru profesional harus memenuhi persyaratan sebagai orang yang bertanggung jawab besar dalam dunia pendidikan, selain itu guru sebagai pendidik bertanggung jawab untuk memberi contoh dan mewariskan nilai serta norma-norma yang baik kepada siswa mereka dan generasi muda (Seknun, 2012: 122).

Guru adalah suatu komponen yang sangat menentukan baik idealnya suatu strategi pembelajaran. Tanpa guru, bagaimanapun bagus dan idealnya suatu strategi, maka strategi itu tidak mungkin bisa diaplikasikan dengan sempurna. (Sanjaya, 2012: 52). Setiap guru memiliki pengalaman, kemampuan, pengetahuan, gaya, teknik dan bahkan pandangan yang berbeda dalam mengajar. Guru yang menganggap mengajar hanya sebatas menyampaikan materi pelajaran pastinya sangat berbeda dengan guru yang menganggap mengajar adalah suatu proses pemberian bantuan kepada peserta didik. Masing-masing perbedaan tersebut dapat mempengaruhi baik dalam penyusunan strategi atau impilmentasi pembelajaran yang dilakukan pada saat mengajar. 


\section{Kompetensi Guru}

Kompetensi dalam bahasa Indonesia merupakan serapan dari bahasa Inggris, competence yang berarti kecakapan dan kemampuan. Kompetensi adalah kumpulan pengetahuan,keterampilan dan perilaku yang harus dimiliki seorang guru untuk mencapai tujuan pembelajaran dalam suatu pendidikan. Kompetensi diperoleh melalui suatu pendidikan, belajar mandiri dan pelatihan. Kompetensi guru merupakan perpaduan antara kemampuan keilmuan, personal, sosial, teknologi dan spiritual yang membentuk suatu kompetensi standar professional guru (Musfah, 2012: 27). Kompetensi memiliki kaitan dengan kemampuan beradaptasi terhadap lingkungan kerja baru, di mana seorang dapat menjalankan tugasnya dengan baik berdasarkan kemampuan yang dimilikinya selama pelatihan atau pendidikan.

Menurut Akmal (2014: 5-7) menyatakan bahwa terdapat dua jenis kompetensi guru, yaitu kompetensi pribadi dan kompetensi profesional. Kompetensi pribadi meliputi (1) Mengembangkan kepribadian yaitu dengan bertakwa kepada Allah swt., ikut berperan penting dalam masyarakat dan mengembangkan sifat terpuji yang menjadi syarat bagi seorang guru, (2) Berkomunikasi dan berinteraksi dengan baik, yaitu berinteraksi dengan sesama untuk meningkatkan kemampuan professional dan berinteraksi dalam masyarakat untuk mencapai visi misi pendidikan, (3) Melaksanakan bimbingan penyuluhan yaitu bimbingan kepada siswayang memiliki masalah kesulitan belajar dan membimbing siswa yang berkebutuhan khusus serta berbakat, (4) Pelaksanaan administrasi sekolah yaitu mengenal proses admininstrasi kegiatan di sekolah dan (5) Melaksanakan penelitian yang sederhana dan mudah untuk keperluan pengajaran sehingga diperoleh suatu hasil ajar yang lebih efisien. Sedangkan kompetensi professional meliputi (1) Penguasaan landasan kependidikan yaitu mengenal apa saja tujuan pendidikan, mengetahui fungsi sekolah dalam masyarakat dan mengetahui apa saja prinsip-prinsip psikologis pendidikan, (2) Menguasai bahan ajar, (3) Mampu menyusun program pengajaran dengan baik dengan memilih dan mengembangkan bahan pengajaran, (4) Melaksanakan program pembelajaran yaitu menciptakan suasana belajar mengajar yang tepat, efektif, inovatif, serta mengelola interaksi belajar mengajar dan (5) Menilai prestasi siswasebagaibahan evaluasi dalam pengajaran dan menilai proses belajar yang dilakukan.

\section{Peranan Guru dalam Proses Pembelajaran}

Peranan guru dalam proses pembelajaran adalah guru sebagai perencana yaitu menganalisis mata pelajaran dan kebutuhan belajar serta merinci tujuan pengajaran. Guru sebagai pengorganisasi yaitu seorang yang profesional selain mengetahui apa yang dikerjakan, juga menyadari prinsip dan alasan hal-hal yang dilakukan atau mengapa hal itu dikerjakan. Guru sebagai pengendali yaitu bertugas menyaring dan mengembangkan metode dan media yang tepat untuk mencapai tujuan. Guru sebagai pengawas bertugas merevisi tujuan, isi, pendekatan, atau metode mengajar sesuai dengan hasil evaluasi (Hasanah, 2001: 57). 
Guru dalam bidang kemanusiaan di sekolah memiliki tanggung jawab sebagai orang tua kedua dari siswa. Guru harus mampu menarik simpati dan perhatian sehingga mampu menjadi panutan oleh siswa. Pelajaran apapun yang diberikan oleh guru hendaknya dapat menjadi motivasi untuk siswa dalam belajar. Masyarakat sangat menghormati seorang guru dilingkungannya karena dari seorang guru diharapkan masyarakat dapat memperoleh ilmu pengetahuan. Kehormatan yang diperoleh seorang guru dari masyarakat, membuat seorang guru memiliki tanggung jawab dan berkewajiban mencerdaskan bangsa menuju pembentukan manusia Indonesia seutuhnya yang berdasarkan pancasila. Taggung jawab guru sebagai pendidik sangat membutuhkan peran penting dari orang tua siswa, karena orang tualah sebagai pendidik awal untuk siswa.

Peranan guru yaitu untuk mengatur kegiatan proses pembelajaran, sumber informasi bagi siswa, pendorong bagi siswa untuk belajar, orang yang memiliki kemampuan untuk menduga kesulitan siswa dan memberikan bantuan kepada siswa sesuai dengan kebutuhannya, penyedia materi dalam proses pembelajaran dan peserta kegiatan yang mempunyai hak dan kewajiban yang sama seperti siswa lainnya, karena guru juga ikut dalam menyumbangkan pendapatnya untuk memecahkan masalah atau mencari kesepakatan bersama sebagaimana siswa lain melakukannya (Hasibuan dan Moedjiono, 2009).

\section{Kesulitan-kesulitan Guru dalam Pengembangan Keterampilan Berpikir Tingkat Tinggi Siswa}

Kelas merupakan tempat berhimpunnya siswa dengan sekian banyak karakter dan kepribadian yang beragam, tentu akan muncul bermacam persoalan yang kompleks sehingga meminta penanganan serius dari seorang guru. Jika persoalan itu dapat ditangani dengan benar maka proses belajar mengajar akan dapat diselenggarakan dengan baik. Sebaliknya, apabila persoalan tersebut dibiarkan, tidak ditangani secara serius, maka proses belajar pun akan menjadi kacau balau (Rusydie, 2011: 77). Keberagamaan siswa di dalam kelas itu mulai dari segi karakter, emosi, intelektual, prilaku, dan kecenderungan, serta kebiasaan. Keberagamaan mereka diperlukan sosok seorang guru yang mampu menanganinya sehingga proses pembelajaran akan berlangsung dengan baik.

Mengelolah kelas merupakan suatu hal yang sulit untuk dihadapi oleh sesorang guru. Guru yang baru menerjunkan diri ke dalam dunia pendidikan seringkali mengalami kesulitan dalam mengelola kelas, namun hal tersebut juga tidak dipungkiri karena guru yang sudah profesionalpun masih mengalami kesulitan tersebut. Gagalnya seorang guru mencapai tujuan pembelajaran sejalan dengan ketidakmampuan guru dalam mengelola kelas. Alat ukur dari kegagalan itu adalah pretasi belajar siswa rendah, tidak sesuai dengan standar atau batas ukuran yang ditentukan. Karena itu dalam mengelola kelas sangat diperlukan kompetensi guru yang sangat penting dikuasai oleh guru dalam kerangka keberhasilan proses belajar mengajar (Djamarah, 2010: 194). 
Guru memiliki tanggung jawab untuk berusaha maksimal, agar kelas dapat dikelola dengan baik. Mengelola kelas yang sangat baik didasarkan pada kemampuan guru untuk mengetahui secara cepat faktor-faktor yang menciptakan kondisi yang menguntungkan dalam proses pembelajaran, mengenal masalah-masalah yang dapat menganggu saat proses pembelajaran berlangsung, menguasai berbagai pendekatan dalam pengelolaan kelas dan mengetahui kapan pendekatan itu dapat digunakan serta pendekatan yang cocok untuk permasalahan dalam pengelolaan kelas. Mengelola kelas tidak seperti pekerjaan juru masak. Masakannya didasarkan pada resep yang telah ditentukan, kualitas masakannya sudah dapat diketahui dengan resep yang telah tersedia, kualitas masakannya sudah dapat diketahui dengan resep yang telah tersedia, tetapi masih membutuhkan penataan masakan dan menciptakan suasana sehingga dapat membangkitkan selera makan kita. Masalah yang timbul dalam kelas biasanya dapat teratasi dengan cara tertentu, pada waktu tertentu dan orang tertentu atau kelompok siswa tertentu. Akan tetapi cara tersebut tidak dapat digunakan oleh orang lain, karena setiap siswa dan guru memiliki karakteristik masing-masing (Latunconsina, 2013: 133).

Masalah-masalah yang muncul sehingga harus dilakukan pengelolaan kelas seperti; 1) kurang kesatuan, tidak ada standar perilaku, 2) reaksi negatif terhadap kelompok, 3) kelas mentoleransi kekeliruan temannya, menerima, dan mendorong perilaku peserta didik yang keliru, 5) mudah mereaksi kepada hal-hal yang negatif, 6) moral yang rendah, permusuhan, dan agresif 7) tidak mampu menyesuaikan dengan lingkungannya yang berubah (Latunconsina, 2013: 135) Pengelolaan kelas terdapat dua masalah yang dapat dihadapi oleh seorang guru yaitu masalah yang datang dari peserta didik secara individual misalnya; peserta didik yang suka mencari perhatian kelas dengan cara membadut, ada juga peserta didik yang meraih perhatian kelas dengan cara menunjukkan kekuatannya suka marah-marah, dan ada masalah dalam kelas yang datang dari kelompok peserta didik, misalnya; ribut dan bermusuhan.

Menurut Djamarah (2010: 195) berbagai macam perilaku siswa yang menyebabkan terjadinya beberapa masalah dalam pengelolaan kelas adalah (1) kurang kesatuan antar siswa karena adanya kelompok-kelompok, dan perbedaan jenis kelamin. (2) kurang memahami antara siswa yang satu dan lainnya sehingga dalam kerja kelompok terjadi keributan, bercerita, meninggalkan kelompok dan sebagainya. (3) adanya pertentangan antara anggota kelompok sehingga menimbulkan perkelahian, keributan, permusuhan, mengucilkan, merendahkab suatu kelompok yang bodoh dan sebagainya. 4) siswa dalam kelas mendukung kekeliruan-kekeliruan temannya. (5) modal rendah seperti kekurangan alat untuk pembelajaran sehingga membuat siswa yang lain bermusuhan dengannya. (6) tidak mampu menyesuaikan dengan lingkungan yang sangat cepat berubah seperti halnya dalam pemberian tugas, ulangan mendadak dan tambahan pelajara.

\section{Berpikir Tingkat Tinggi}

Berpikir adalah suatu proses simbolis (representasi mental) untuk memanipulasi informasi guna memecahkan masalah tertentu dan menghasilkan ide-ide kreatif. 
Berpikir merupakan suatu proses kompleks yang terjadi dengan mengkonstruksikan skema-skema kognitif dan mengkategorikan setiap stimulus ke dalamnya. Berpikir juga disebut sebagai proses memecahkan masalah. Plotnik memaparkan bahwa berpikir seringkali disamakan artinya dengan reasoning, yang berarti suatu proses mental yang melibatkan pengetahuan untuk mencapai tujuan tertentu yang mencakup pememcahan masalah, perencanaan dan pengambilan keputusan. Berpikir berfungsi untuk memecahkan masalah, mengambil keputusan dan menghasilkan ide-ide kreatif (Hirmawan, 2013: 11-12). Berpikir merupakan proses mental yang dilakukan manusia untuk menghasilkan ide kreatif yang artinya mampu untuk menciptakan hal yang baru. Hal ini berarti berpikir merupakan proses untuk menghasilkan ide-ide baru.

Keterampilan berpikir yaitu kemampuan memproses informasi, kemampuan penalaran, keterampilan penyelidikan, kreatifketerampilan berpikir dan keterampilan evaluasi. Meskipun strategi dan pendekatan yang digunakan untuk mengajarkan keterampilan berpikir bervariasi dalam format mengidentifikasi elemen dari kerangka umum untuk pengajaran keterampilan berpikir yaitu adanya keyakinan mendasar bahwa keterampilan kognitif anak-anak dapatdikembangkan saat keterampilan dan metakognisi berpikir yang dibuat eksplisit dalam kurikulum, pembelajaran kolaboratif, tujuan untuk membuat berpikir yang baik, dan gagasan bahwaruang kelas dan seluruh sekolah harus berfungsi sebagai kerangka kerja di mana dapat memupuk pemikiran yang baik (Jones, 2008: 310).

Kemampuan berpikir tingkat tinggi (High Order Thinking Skill) adalah suatu proses berpikir yang tidak sekedar menghafal dan menyampaikan kembali informasi yang telah didapatkan. Kemampuan berpikir tingkat tinggi yaitu menghubungkan dan mentransformasi pengetahuan serta pengalaman yang telah dimiliki untuk berpikir secara kritis dan kreatif untuk upaya menentukan keputusan dan memecahkan sebuah masalah pada situasi tertentu. Secara umum, ada beberapa aspek yang menunjukkan kemampuan berpikir tingkat tinggi yang dimiliki oleh seseorang yaitu kemampuan berpikir kritis dan kreatif serta memecahkan suatu permasalahan (Rofiah, Aminah, dan Ekawati, 2013: 18).

Kemampuan berpikir tingkat tinggi mampu membuat manusia menjadi lebih terbuka dan mudah menyesuaikannya dengan situasi tertentu dan permasalahan serta dapat mengembangkan diri mereka dalam membuat keputusan, penilaian dan penyelesaian masalah. Kemampuan berpikir dapat dilihat dengan kemampuan mengetahui asumsi yang diberikan, kemampuan menentukan pokok permasalahan, kemampuan untuk menentukan akibat dari suatu ketentuan yang telah diambil, kemampuan mendeteksi adanya suatu bias pada suatu sudut pandang yang berbeda satu sama lain, kemampuan mengungkap data dalam penyelesaian masalah dan kemampuan mengevaluasi pendapat-pendapat yang relevan atau searah dalam penyelesaian suatu masalah yang ada. 


\section{Ciri-Ciri Berpikir Tingkat Tinggi}

Menurut Shaleh (2009: 62) ciri-ciri secara umum yang menandai seseorang berpikir tingkat tinggi yaitu (1) Kemampuan kognitif, maksudnya kecerdasan berada di atas rata-rata, kemampuan menciptakan gagasan baru, gagasan-gagasan yang berlainan dari pendapat orang lain dan fleksibilitas, (2) Sikap yang terbuka, orang yang berpikir tingkat tinggi selalu menyiapkan dirinya untuk menerima pendapat eksternal, memiliki pikiran yang beragam dan pandangan tentang pengetahuan yang luas. (3) Sikap yang bebas, dan percaya pada diri.

Menurut Kuswana (2012: 205) ciri-ciri orang yang memiliki kemampuan berpikir tingkat tinggi adalah sebagai berikut(1) Sikap ingin tahu, ditunjukkan dengan kebiasaan bertanya mengenai suatu hal yang tidak diketahuinya, (2) Sikap kritis, ditunjukkan oleh kebiasaan untuk mencari informasi lalu mengolahnya untuk dipelajari, (3) Sikap objektif, ditunjukkan dengan kebiasaan seseorang menyampaikan informasi sesuai pengetahuan yang telah dipelajari, (4) Sikap rela, ditunjukkan dengan kebiasaan untuk menyampaikan rasa kagum terhadap karya orang lain. (5) Sikap terbuka, ditunjukkan dengan kebiasaan untuk mendengarkan dan menerima pendapat orang lain, kritik dan penjelasan orang lain dan (6) Sikap berani, ditunjukkan dengan kebiasaan untuk mengatakan kebenaran atas suatu dasar kajian, penelitian yang dilandasi oleh fakta dan pembuktian yang real.

Orang-orang yang memiliki kemampuan berpikir tingkat tinggi ditandai dengan rasa ingin tahu yang dimiliki orang tersebut sangat tinggi dibandingkan dengan orangorang memilki kemampuan berpikir tingkat rendah. Rasa ingin tahu yang dimiliki orang tersebut membuat mereka berani dalam hal melakukan penelitian untuk menemukan hal yang baru. Hasil penemuan orang berpikir tingkat tinggi tersebut tidak membuatnya merasa puas, tetapi mereka akan berusaha lebih maju agar penemuan yang mereka peroleh dapat tergolong sempurna. orang berpikir tingkat tinggi memilki daya serap ingatan yang kuat.

\section{METODOLOGI PENELITIAN}

Jenis penelitian yang digunakan adalah penelitiandeskriptif kualitatif, yaitu metode penelitian yang digunakan untuk membuat pecandraan secara sistematis, faktual, dan akurat mengenai fakta-fakta dan sifat-sifat populasi atau daerah tertentu (Suryabrata, 2013: 75). Penelitian ini dilaksanakan di SMA Negeri 2 Gowa di Jalan Pendidikan Limbung, Adapaun Sampel purposif (purposive sample) adalah 3 guru biologi dan 67 siswa kelas XII di SMA Negeri 2 Gowa. Penelitian ini dilaksanakan oleh peneliti di kelas XII IPA 1 dan XII IPA 9 dalam pengambilan data untuk mengetahui kemampuan berpikir tingkat tinggi siswa.

Sedangkan untuk pengambilan data untuk mengetahui kesulitan guru dan solusi dilaksanakan peneliti di ruang guru, dimana peneliti menggali informasi kepada 3 orang guru biologi. Instrumen adalah alat pada waktu peneliti menggunakan suatu metode (Arikunto, 2013: 192). Instrumen penelitian juga merupakan alat yang dapat digunakan 
untuk mengumpulkan data penelitian (Wina, 2010: 84). Adapun alat-alat yang digunakan dalam penelitian ini adalah tes dan pedoman wawancara. Selanjutnya hasil penelitian dioleh dengan menggunakan teknik analisis data kualitatif dengan model interaktif. Terdapat tiga tahapan dalam teknik analisis data ini yakni reduksi data, penyajian data, dan penarikan kesimpulan atau verifikasi(Miles dan Huberman, 1992: 16).

\section{HASIL PENELITIAN DAN PEMBAHASAN}

\section{Gambaran Kemampuan Berpikir Tingkat Tinggi Siswa}

Proses pelaksanaan yang dilakukan peneliti untuk menguji kemampuan berpikir tingkat tinggi siswa dilaksanakan di sekolah SMA Negeri 2 Gowa pada tanggal 6 November 2017 - 7 November 2017. Pelaksanaan untuk menguji kemampuan berpikir tingkat tinggi siswa dilakukan selama dua hari yaitu hari pertama dilakukan di kelas XII IPA 1 dan hari kedua dilakukan di kelas XII IPA 9.

Pada tahap ini peneliti mengumpulkan data dengan menggunakan tes tertulis yang berupa essay. Soal-soal ini terdiri dari 4 butir soal untuk rana koginitif C4, 2 butir C5 dan 2 butir C6. Soal ini kemudian diberikan kepada siswa kelas XII IPA 1 dan XII IPA 9 SMA Negeri 2 Gowa. Berikut adalah uraian hasil tes tersebut.

Adapun hasil tes yang diperoleh kelas XII IPA 1 adalah Amal Khairin memperoleh hasil 39. Fadel Muhammad memperoleh hasil 70. Gebby Bahar memperoleh hasil 69. Irmayani memperoleh hasil 33. Karmila memperoleh hasil 55.M. Agung memperoleh hasil 38.Muh. Fikri Fadillah memperoleh hasil 37. Muh. Rafli memperoleh hasil 44. M. Syahrir memperoleh hasil 55. Sedangkan hasil tes yang diperoleh untuk kelas XII IPA 9 adalah Arifatunnisa memperoleh hasil 56. Ariska Bimasari memperoleh hasil 49.Muhammad Andi Satrio memperoleh hasil 36. Muhajrin Makkawaru memperoleh hasil 57. Muh. Irsyad Fauzi K. memperoleh hasil 55.

Berdasarkan uraian diatas merupakan hasil tes yang telah diberikan kepada siswa dapat dinyatakan bahwa kemampuan berpikir tingkat tinggi siswa kelas XII IPA di sekolah tersebut tergolong rendah. Hal tersebut ditunjukkan oleh jawaban siswa pada tes yang telah diberikan. Dimana terdapat $7 \%$ siswa yang mampu menyelesaikan soal untuk ranah kognitif $\mathrm{C} 4,10 \%$ siswa yang mampu menyelesaikan soal untuk ranah kognitif C5 dan 3\% siswa yang mampu menyelesaikan soal untuk ranah kognitif C6.

\section{Gambaran Kesulitan Guru dalam Pengembangan Keterampilan Berpikir Tingkat Tinggi Siswa}

Berdasarkan hasil wawancara terhadap guru Biologi di SMA Negeri 2 Gowa yang dilaksanakan pada tanggal 7-8 November 2017 guru memiliki beberapa kesulitan dalam mengembangkan keterampilan berpikir tingkat tinggi siswa. Kesulitan guru untuk perencanaan pembelajaran, guru IPA 1 mengatakan bahwa kemampuan siswa yang berbeda-beda membuat saya kesulitan dalam membuat RPP yang berbasis 
pengembangan keterampilan berpikir tingkat tinggi. Sedangkan guru IPA 9 mengatakan bahwa Saya kurang memahami mengenai cara-cara tertentu dalam pembelajaran yang mendukung pengembangan keterampilan berpikir tingkat tinggi, juga kurang mampu dalam menentukan metode dan model pembelajaran. Kesulitan guru dalam pelaksanaan pembelajaran guru IPA 1 mengatakan bahwa dalam pelaksaanan pembelajaran apersepsi sangat diperlukan untuk menarik perhatian siswa agar fokus terhadap materi pelajaran yang akan diberikan oleh guru. Namun, pada kenyataannya ketika saya melakukan apersepsi cukup sulit untuk membuat siswa merasa tertarik dalam merespon apersepsi yang saya berikan sehingga hal tersebut juga berdampak terhadap motivasi siswa dalam mengikuti pembelajaran. Terlebih lagi ketika siswa harus dihadapkan terhadap materi yang mengharuskan siswa untuk mampu mengasah kemampuan berpikir tingkat tinggi mereka. Guru IPA 9 mengatakan bahwa saya merasa kesulitan dalam melakukan apersepsi yang merangsang siswa untuk mengembangkan keterampilan berpikir tingkat tinggi, terlebih lagi sikap siswa yang berbeda-beda dalam menanggapi apersepsi yang diberikan hanya beberapa siswa yang cenderung aktif dalam kegiatan apersepsi. Hal ini juga mengakibatkan siswa kurang termotivasi dalam mengikuti pembelajaran yang saya ajarkan.

Kesulitan guru dalam membuat tes untuk mengukur kemampuan berpikir tingkat tinggi, guru IPA 1 mengatakan bahwa beliau tentu saja saya mengalami kesulitan dalam membuat tes karena rana kognitif yang digunakan untuk membuat tes tersebut berada di rana kognitif yang cukup tinggi dimana di dalam tes tersebut harus mampu untuk mengukur kemampuan berpikir tingkat tinggi siswa. Sedangkan guru IPA 9 mengatakan bahwa kesulitan yang sering saya hadapi adalah menyesuaikan antara soal dengan kata kerja operasional yang terdapat dalam indikator pembelajaran berbasis pengembangan kemampuan berpikir tingkat tinggi. Sehingga dalam soal yang selalu saya berikan kepada siswa tidak jauh dari kemampuan memahami dan menerapkan. Tetapi kemampuan untuk menganalisis paling setidaknya satu yang mewakili dari sekian soal yang saya berikan.

Kesulitan guru dalam mengukur kemampuan berpikir tingkat tinggi siswa guru IPA 1 mengatakan bahwa ada beberapa siswa yang mempunyai perbedaaan cara untuk menunjukkan kemampuannya dalam berpikir, seperti ada anak yang cenderung mampu mengesplor kemampuan berpikir yang dimilikinya melalui lisan namun kesulitan menuangkannya dalam bentuk tulisan begitupun sebaliknya. Kesulitan itulah yang saya alami saat mengukur kemampuan berpikir tingkat tinggi siswa. Sedangkan guru IPA 9 mengatakan bahwa dalam mengukur kemampuan berpikir tingkat tinggi saya sering mengalami kesulitan hal tersebut terjadi karena keadaan siswa yang berbeda seperti halnya dalam proses pelaksanaan pembelajaran dimana ada yang siswa aktif untuk mengeluarkan pendapatnya terhadap materi yang dijelaskan serta jawabannya tepat saat diberikan pertanyaan secara lisan, namun saat diberikan tes tertulis siswa tersebut cenderung berada di bawah rata-rata dalam artian tersebut siswa dalam menjawab soal tes yang diberikannya itu kurang, begitupun sebaliknya ada siswa yang tidak aktif 
dalam proses pelaksanaan pembelajaran namun saat diberi tes tertulis dia mendapatkan nilai yang memuaskan.

Berdasarkan uraian di atas dapat disimpulkan bahwa kesulitan yang dialami guru terdiri dari beberapa diantaranya adalah tidak mampu mengatasi kemampuan siswa yang berbeda-beda, kurang memahami mengenai cara-cara tertentu dalam pembelajaran yang mendukung pengembangan keterampilan berpikir tinggi siswa, kurang mampu dalam menentukan metode dan model pembelajaran yang tepat, kurang memahami mengenai pengembangan keterampilan berpikir tingkat tinggi, melakukan apersepsi untuk merangsang siswa dalam mengembangkan keterampilan berpikir tingkat tinggi siswa, membuat siswa merasa tertarik dalam merespon apersepsi yang diberikan, kurang mampu menyesuaikan antara soal dengan kata kerja operasional yang terdapat dalam indikator pembelajaran yang berbasis pengembangaan keterampilan berpikir tingkat tinggi, dan belum mampu mengatasi siswa yang mempunyai perbedaaan cara untuk menunjukkan kemampuannya dalam berpikir.

\section{Gambaran Solusi mengatasi Guru dalam Pengembangan Keterampilan Berpikir Tingkat Tinggi Siswa.}

Berdasarkan hasil wawancara terhadap guru Biologi di SMA Negeri 2 Gowa yang dilaksanakan pada tanggal 3 November dan 6 November 2017 berikut adalah uraian solusi untuk mengatasi kesulitan yang dihadapi guru dalam mengembangkan keterampilan berpikir tingkat tinggi meliputi kesulitan dalam perencanaan pembelajaran, pelaksanaan pembelajaran, membuat butir tes dan mengukur kemampuan berpikir siswa.

Solusi pertama untuk mengatasi kesulitan dalam perencanaan pembelajaran guru IPA 1 mengatakan bahwa cara yang saya tempuh untuk mengatasi kesulitan dalam membuat RPP yaitu dengan memperhatikan kondisi setiap siswa yang berada di dalam kelas saat pembelajaran berlangsung sehingga untuk pembuatan RPP untuk materi selanjutnya akan mampu mengetahui kondisi siswa agar mereka dapat mengikuti pelajaran dengan baik dan mampu membuat perkembangan kepada siswa dalam hal berpikir sehingga mereka memiliki rasa percaya diri dan saling menghargai satu sama lain.Siswa yang memiliki kemampuan di atas temannya saya harapkan dia bisa membantu temannya dan teman yang lainnya akan merasa terbantu, karena belajar dengan teman sendiri itu membuat mereka lebih mudah untuk memahami suatu materi serta dengan bimbingan yang saya arahkan sehingga keadaan kelas tidak menjadi ribut. Sedangkan guru IPA 9 mengatakan bahwa untuk mengatasi kesulitan dalam membuat RPP saya berharap sekiranya diadakan pelatihan mengenai pengembangan keterampilan berpikir tingkat tinggi siswa. Agar saya dapat meningkatkan kemampuan saya dalam mengajar dan mampu untuk mengembangkan keterampilan berpikir tingkat tinggi siswa.

Solusi kedua untuk mengatasi kesulitan guru dalam pelaksanaan pembelajaran. Guru IPA 1 mengatakan bahwa ketika saya mengalami kesulitan dalam menarik perhatian siswa saat melakukan apersepsi dan tidak mampu untuk membuat siswa termotivasi maka cara saya untuk mengatasi kesulitan tersebut adalah melakukan 
kegiatan apersepsi yang berbeda dengan biasanya sehigga menimbulkan daya tarik siswa dan menumbuhkan motivasi kepada siswa dalam mengikuti pembelajaran. Sedaangkan untuk guru IPA 9 mengatakan bahwa harus terus belajar untuk meningkatkan kapasitas yang diperlukan dalam proses pembelajaran. Salah satunya dengan giat membaca kiat-kiat yang harus dilakukan guru dalam terciptanya pembelajaran yang baik terutama dalam memberikan apersepsi dan motivasi kepada siswa agar proses pembelajaran berjalan dengan baik serta siswa mendapatkan hak yang seharusnya mereka dapatkan di sekolah.

Solusi ketiga untuk mengatasi kesulitan guru dalam membuat butir tes untuk mengukur kemampuan berpkir tingkat tinggi. Guru IPA 1 mengatakan bahwa cara yang saya lakukan yaitu lebih banyak membaca referensi terkait bagaimana cara membuat tes untuk mengukur kemampuan berpikir tingkat tinggi siswa. Sedangkan guru IPA 9 mengatakan bahwa saya akan membiasakan diri untuk membaca soal-soal untuk mengukur kemampuan berpikir tingkat tinggi siswa dan membuat soal yang sesuai dengan kata kerja operasional dalam indikator pembelajaran berbasis pengembangan keterampilan berpikir tinggi siswa.

Adapun kesulitan keempat untuk mengatasi kesulitan guru dalam mengukur kemampuan berpikir tingkat tinggi siswa. Guru IPA 1 mengatakan bahwa cara yang saya lakukan untuk mengatasi kesulitan dalam mengukur kemampuan berpikir tingkat tinggi yaitu mengakumulasikan nilai yang diperoleh secara lisan selama pembelajaran berlangsung serta hasil tes tertulis yang diberikan. Sedangkan guru IPA 9 mengatakan bahwa untuk mengatasi kesulitan yang saya hadapi yaitu dengan cara belajar untuk membuat instrumen penilaian yang sesuai dengan indikator yang hendak dicapai. Indikator yang hendak dicapai tersebut pengembangan keterampilan berpikir tingkat tinggi siswa.

Berdasarkan uraian di atas dapat disimpulkan bahwa solusi yang ditempuh guru untuk mengatasi kesulitan yang dihadapi dalam pembelajaran adalah melakukan kegiatan pembelajaran secara berkelompok kepada siswa agar mereka saling membantu satu sama lain, diadakan pelatihan mengenaipengembangan keterampilan berpikir tingkat tinggi siswa, melakukan kegiatan apersepsi dengan gaya yang berbeda dengan biasanya sehigga menimbulkan daya tarik siswa dan menumbuhkan motivasi kepada siswa dalam mengikuti pembelajaran, belajar untuk meningkatkan kapasitas yang diperlukan dalam proses pembelajaran, lebih banyak membaca referensi terkait bagaimana cara membuat tes untuk mengukur kemampuan berpikir tingkat tinggi siswa. Mengakumulasikan nilai yang diperoleh secara lisan selama pembelajaran berlangsung serta hasil tes tertulis yang diberika, belajar untuk membuat instrumen penilaian yang sesuai dengan indikator yang hendak dicapai. 


\section{Pembahasan}

\section{Gambaran Kemampuan Berpikir Tingkat Tinggi Siswa}

Hasil tes yang telah dilakukan di sekolah SMA Negeri 2 Gowa dapat dinyatakan bahwa kemampuan berpikir tingkat tinggi siswa kelas XII IPA di sekolah tersebut masih tergolong rendah. Hal tersebut diketahui dari hasil tes yang telah dilakukan berupa tes essay yang mampu mengukur kemampuan berpikir tingkat tinggi siswa. Tes yang diberikan dikatakan mampu mengukur kemampuan berpikir tingkat tinggi karena rana kognitif di dalam soal tersebut mencakup C4, C5 dan C6 yang sesuai dengan taksonomi Bloom.

Hal yang menyebabkan kemampuan berpikir tingkat tinggi yang dimiliki siswa SMA Negeri 2 Gowa tergolong rendah karena kesulitan yang dihadapi oleh guru saat proses pembelajaran berlangsung untuk mengembangkan keterampilan berpikir tingkat tinggi.

\section{Gambaran Kesulitan Guru dalam Guru dalam Pengembangan Keterampilan Berpikir Tingkat Tinggi Siswa}

Kesulitan yang dialami guru terdiri dari beberapa diantaranya adalah tidak mampu mengatasi kemampuan siswa yang berbeda-beda. Kemampuan masing-masing siswa dalam belajar memang berbeda-beda. Perbedaan kemampuan yang dimiliki oleh setiap siswa yaitu terlihat dari kemampuan mereka untuk menangkap materi pelajaran yang dijelaskan oleh seorang guru saat pembelajaran berlangsung dimana terdapat siswa yang dengan cepat menangkap dan memahami materi pelajaran, ada pula siswa yang membutuhkan waktu lama untuk memahami materi pelajaran. Hal tersebut disebabkan karena kemampuan pengetahuan setiap siswa dan kemauan siswa untuk menerima materi pelajaran. Perbedaan dan keterebatasan pengetahuan yang dimiliki siswa dalam belajar dapat menghambat proses pembelajaran yang berlangsung. Namun hal tersebut tidak bisa dipungkiri karena terkait dengan kemampuan pengetahuan siswa yang merupakan aspek alami.

Kurang memahami mengenai cara-cara tertentu dalam pembelajaran dan kurang mampu dalam menentukan metode dan model pembelajaran yang tepat. Pada dasarnya guru adalah seorang pengajar yang memiliki kemampuan untuk mengubah kemampuan berpikir siswa dari tidak tahu mejadi tahu serta mendewasakannya karena merupakan tanggung jawab yang dimiliki seorang guru. Menjalankan tanggungjawab yang dimiliki seorang guru salah satu yang harus dilakukan yaitu mengajar di dalam kelas sehingga berhadapan langsung dengan siswa. Salah satu yang paling penting adalah penampilan guru di kelas, seorang guru harus mampu menguasai keadaan kelas sehingga mampu tercipta suasana belajar yang menyenangkan. Agar tercipta suasana belajar yang menyenangkanseorang guru harus mampu untuk menerapkan metode dan model pembelajaran yang sesuai dengan karakterisktik siswa. 
Kurang memahami mengenai pengembangan keterampilan berpikir tingkat tinggi. Pada umumnya kemampuan peserta didik di Indonesia sangat rendah dalam memahami informasi yang komplek, teori analisis dan pemecahan masalah, pemakaian alat dan prosedur serta melakukan investigasi. Kemampuan itu dikenal dengan kemampuan berpikir tingkat tinggi. Untuk melakukan pembelajaran untuk pengembangan kemampuan berpikir tingkat tinggi harus diawali dengan kemampuan guru dalam penyelesaian masalah dalam proses pembelajaran itu sendiri. Hal utama yang harus dilakukan guru adalah guru dapat menganalisis kemampuan siswa dan kesiapannya dalam mengikuti suatu pembelajaran.

Melakukan apersepsi untuk merangsang siswa dalam mengembangkan keterampilan berpikir tingkat tinggi siswa dan membuat siswa merasa tertarik dalam merespon apersepsi yang diberikan. Guru tentunya sudah familiar dengan istilah apersepsi ketika kegiatan belajar berlangsung. Apersepsi pada prinsipnya adalah kegiatan pendahuluan pembelajaran dengan tujuan untuk membangkit motivasi belajar siswa. Pemilihan metode yang salah tersebut membuat siswa tidak terangsang untuk belajar dan kemauan dari dalam diri untuk mencari ilmu mereka sangat rendah. Apersepsi yang mampu untuk membangkitkan motivasi belajar mereka. Apersepsi sebisa mungkin harus mengandung makna kontekstual artinya diawali dari pengalaman siswa, atau siswa terlibat dalam kegiatan pendahuluan pembelajaran setelah itu baru guru mengarahkan materi pelajaran kepada hal-hal yang bersifat konsep.

Kurang mampu menyesuaikan antara soal dengan kata kerja operasional yang terdapat dalam indikator pembelajaran yang berbasis pengembangaan keterampilan berpikir tingkat tinggi dan belum mampu mengatasi siswa yang mempunyai perbedaaan cara untuk menunjukkan kemampuannya dalam berpikir. Selain mengajar guru juga dituntut untuk melakukan kegiatan evaluasi terhadap siswa karena dengan evaluasi ini maka tujuan dari pembelajaran bisa diketahui apakah sukses atau tidak. Namun demikian, tidak semua evaluasi mampu mengukur hal tersebut, terkadang instrumen tes yang dipergunakan tidak layak yang menyebabkan tujuan dari pembelajaran sulit dipastikan keberhasilannya. Oleh sebab itu guru setidaknya harus mampu membuat serta menyusun soal dengan benar sehingga bisa digunakan untuk megukur hasil belajar dan kesuksesan dari tujuan pembelajaran.

\section{Gambaran Solusi mengatasi Guru dalam Pengembangan Keterampilan Berpikir Tingkat Tinggi Siswa.}

Berdasarkan hasil wawancara terhadap guru Biologi di SMA Negeri 2 Gowa yang dilaksanakan pada tanggal 7-8 November 2017 berikut adalah melakukan kegiatan pembelajaran secara berkelompok kepada siswa agar mereka saling membantu satu sama lain. Belajar kelompk adalah sebuah metode pembelajaran dimana siswa belajar bekerja sama dengan sebua kelompok untuk menyelesaikan tugas belajarnya. Saat belajar kelompok ada suatu proses transfer ilmu yang melibatkan lebih dari satu orang, dimana diantara orang yang satu dengan yang lain saling melengkapi. Ada hal-hal menarik yang dibicarakan saat kita berkumpul dengan teman-teman. Tidak hanya bergurau atau sekedar bercengkrama. Namun, juga dapat kita manfaatkan untuk belajar 
kelompok. Yaitu mempelajari suatu masalah secara bersama-sama, dapat melauli diskusi, Tanya jawab, dan memecahkan masalah.

Diadakan pelatihan mengenai pengembangan keterampilan berpikir tingkat tinggi siswa. Pelatihan yang harus dilakukan oleh guru yaitu guru diberikan pemahaman mengenai berpikir tingkat tinggi, berpikir kritis sebagai salah satu komponen dalam proses berpikir tingkat tinggi, menggunakan dasar menganalisis setiap masalah dalam kehidupan sehari-hari dan memunculkan wawasan terhadap tiap-tiap makna dalam materi pembelajaran yang kurang dipahami siswa. Mengembangkan pola penalaran yang sifatnya terpadu atau saling terikat antara satu dengan yang lainnya dan logis. Jika pola pikir tersebut dikembangkan melalui pengolahan materi subjek biologi hal tersebut digunakan dalam pembelajaran dengan baik kepada siswa sekolah lanjutan, maka para guru sekaligus akan memperoleh pembinaan dalam keterampilan berpikir tingkat tinggi maupun dalam penguasaan materi subjek. Kemampuan ini diharapkan dapat ditularkan kepada para siswanya di lapangan.

Melakukan kegiatan apersepsi dengan gaya yang berbeda dengan biasanya sehigga menimbulkan daya tarik siswa dan menumbuhkan motivasi kepada siswa dalam mengikuti pembelajaran. Sebagai guru, tentunya kita sering menghadapi berbagai macam ekspresi (emosi) siswa saat mereka baru saja tiba di sekolah. Perbedaan ekspresi yang dimiliki seorang siswa saat awal pembelajaran berlangsung akan mempengaruhi konsentrasi siswa saat belajar. Oleh karena itu guru memiliki tanggung jawab untuk membuat siswa siap untuk menerima pembelajaran dengan baik. Jika kegiatan diawal pembelajaran kita tidak mampu untuk membuat siswa konsentrasi menerima pembelajaran maka kegiatan pembelajaran selanjutkan tidak akan terbangun sehingga membuat siswa tidak dapat menerima informasi yang akan disampaikan guru. Jika hal tersebut terjadi maka dapat mempengaruhi hasil berlajar siswa. Untuk menghindari hal tersebut diperlukan kemampuan guru untuk melakukan apersepsi dengan baik di awal pembelajaran agar siswa termotivasi untuk mengikuti pembelajaran karena dengan adanya apaersepsi yang dilakukan di awal kegiatan pembelajaran membuat otak anak siap untuk menerima materi pembelajaran. Apersepsi yang tepat membuat siswa merasa nyaman dan senang yang ditandai dengan wajah yang ceria, tersenyum, bahkan tertawa.

Membaca referensi lebih banyak terkait bagaimana cara membuat butir tes untuk mengukur kemampuan berpikir tingkat tinggi siswa. Tes merupakan salah satu alat evaluasi untuk mengukur kemampuan berpikir siswa sehingga guru diharapkan mampu untuk membuat tes yang sesuai dengan indikator yang ingin dicapai. Seperti halnya untuk mengukur kemampuan berpikir tingkat tinggi siswa maka tes yang digunakan harus memuat rana kognitif yang mampu mengukur kemampuan berpikir tingkat tinggi siswa. Dalam taksonomi Bloom rana kognitif dalam berpikir tingkat tinggi yaitu dari C4, C5, dan C6. Jadi untuk pembuatan tes harus mencakup rana kognitif tersebut dan kata kerja operasional harus sesuai sehingga mampu mengukur kemampuan siswa dengan tepat.

Mengakumulasikan nilai yang diperoleh secara lisan selama pembelajaran berlangsung dan hasil tes tertulis yang diberikan serta belajar untuk membuat instrumen 
penilaian yang sesuai dengan indikator yang hendak dicapai. Selain mengajar guru juga dituntut untuk melakukan kegiatan evaluasi terhadap siswa karena dengan evaluasi ini maka tujuan dari pembelajaran bisa diketahui apakah sukses atau tidak. Penilaian adalah cara yang dilakukan oleh seorang guru untuk mengetahui sejauh mana kemampuan siswa dalam memahami sebuah materi pembelajaran yang diberikannya yang dapat dilihat dari hasil belajar siswa dan digunakan sebagai tolak ukur untuk mengetahui kemampuan guru dalam menyalurkan pengetahuaanya kepada siswa. Hasil penilaian terdiri atas dua bagian yaitu penilaian kualitatif (pernyataan naratif dalam kata-kata) dan nilai kuantitatif (berupa angka). Hasil penilaian dapat diketahui dengan cara memberikan tes kepada siswa sehingga guru bisa memperoleh informasi tentang sejauh mana pemgetahuan siswa terhadap pembelajaran. Untuk mengetahui kemampuan siswa dalam mencapai tujuan pembelajaran itu berhasil, maka guru sebaiknya menggunakan instrumen penilaian yang sesuai dengan karakteristik tujuan yang didalamnya mencakup tentang standar kompetensi maupun kompetensi dasar yang secara berkala dan berkesinambungan. Guru harus memiliki kemampuan analisis yang cermat dari subskills dan pengetahuan dalam standar-standar yang seharusnya dikuasai siswa. Artinya seorang guru harus cermat dan teliti dalam mengolah materi dan penilaian yang sesuai dengan standar pencapaian.

\section{KESIMPULAN}

Berdasarkan hasil penelitian dan pembahasan yang telah diuraikan, maka simpulan dari penelitian ini adalah (1) Kemampuan berpikir tingkat tinggi siswa di SMA Negeri 2 Gowa masih tergolong rendah dimana dapat dilihat dari perolehan nilai siswa kebanyakan memperoleh nilai dibawah 50 yang ditunjukkan pada hasil tes dengan menggunakan soal essay yang memiliki rana kognitif C4, C5, dan C6. (2) Kesulitankesulitan yang dihadapi oleh guru dalam mengembangkan keterampilan berpikir tingkat tinggi siswa SMA Negeri 2 Gowa diantaranya adalah guru sulit mengatasi kemampuan siswa yang berbeda-beda, kurang memahami mengenai cara-cara tertentu dalam pembelajaran, kurang mampu dalam menentukan metode dan model pembelajaran yang tepat, kurang memahami mengenai pengembangan keterampilan berpikir tingkat tinggi, melakukan apersepsi untuk merangsang siswa, membuat siswa merasa tertarik dalam merespon apersepsi yang diberikan, kurang mampu menyesuaikan antara soal dengan kata kerja operasional yang terdapat dalam indikator pembelajaran, dan belum mampu mengatasi siswa yang mempunyai perbedaaan cara untuk menunjukkan kemampuannya dalam berpikir. (3) Beberapa solusi yang dapat ditempuh untuk mengatasi kesulitan guru dalam mengembangkan keterampilan berpikir tingkat tinggi yaitu melakukan kegiatan pembelajaran secara berkelompok kepada siswa, diadakan pelatihan mengenai pengembangan keterampilan berpikir tingkat tinggi siswa, melakukan kegiatan apersepsi dengan gaya yang berbeda dengan biasanya, belajar untuk meningkatkan kapasitas yang diperlukan dalam proses pembelajaran, lebih banyak membaca referensi terkait bagaimana cara membuat tes untuk mengukur kemampuan berpikir tingkat tinggi 
siswa, mengakumulasikan nilai yang diperoleh secara lisan selama pembelajaran berlangsung dan hasil tes tertulis yang diberikan, belajar untuk membuat instrumen penilaian yang sesuai dengan indikator yang hendak dicapai.

\section{UCAPAN TERIMAKASIH}

Penulis mengucapkan terima kasih terkhusus kepada guru Biologi dan siswa SMA Negeri 2 Gowa yang telah ikut berpartispasi dalam penelitian yang telah dilakukan.

\section{DAFTAR PUSTAKA}

Arikunto, Suharsimi. 2013. Prosedur Penelitian. Cet. XV. Jakarta: Rineka Cipta.

Djamarah, Syaiful Bahri. 2010. Strategi Belajar Mengajar. Cet. IV. Jakarta: Rineka Cipta.

Hasanah, Aan. 2012. Pengembangan Profesi Guru. Bandung: CV. Pustaka Setia.

Hasibuan dan Moedjiono. 2009.Proses Belajar Mengajar. Bandung: PT. Remaja Rosdakarya.

Hawl, Akmal. 2014. Kompetensi Guru Pendidikan Agama Islam. Cet. II. Jakarta: PT. Rajagrafindo Persada.

Hirmawan, Karel Karsten. 2013. Pemikiran Magis, Ketika Batas Antara Magis dan Logis Menjadi Bias. Cet. I. Jakarta: PT Indeks.

Jones, Honneke. “ The Curriculum Journal Thoughts on teaching thinking: perceptions of practitioners with a shared culture of thinking skills education", Newcastle University, UK 19, no. 3 (2008): h. 309-324.

Kuswana, Wowo Sunaryo. 2012.Taksonomi Kognitif, Perkembangan Ragam Berpikir. Cet. I. Bandung: PT. Remaja Rosdakarya.

Latunconsina, Nurkhalisa. 2013, Pengelolaan Kelas dalam Pembelajaran, Cet. I; Makassar: Alauddin University Press.

Matthew B. Miles, Matthew B dan A. Michael Huberman, Michael A. 1992. Qualitative Data Analysis (Analisis Data Kualitatif), terj. Tjetjep Rohendi, Cet. I; Jakarta: UI-Press.

Musfah, Jejen. 2012.Peningkatan Kompetensi Guru, Cet. II. Jakarta: Kencana Prenada Media Group.

Rofiah, Rofiah, Nonoh Siti Aminah, Elvin Yusliana Ekawati, "Penyusunan Instrumen Tes Kemampuan Berpikir Tingkat Tinggi Fisika Pada Siswa SMP”, FKIP Universitas Sebelas Maret 1, no. 2 (2013): h. 17-22.

Rusydie, Salman. 2011. Prinsip-Prinsip Manajemen Kelas. Jogjakarta: DIVA Press.

Shaleh, Abdul Rahman. 2009. Psikologi, Suatu Pengantar dalam Perspektif Islam. Cet. IV. Jakarta: Putra Grafika. 
Seknun, M. Yusuf, “Kedudukan Guru Sebagai Pendidik”, Lentera pendidikan, LPTK dan Konsorius Dosen Ilmu Tarbiyah dan Keguruan, Universitas Islam Negeri 15no.1(2012): h.122-135.

Wina, Sanjaya. 2009.Kurikulum dan Pembelajaran, Teori dan Praktik Pengembangan Kurikulum Ttingkat Satuan Pendidikan ( KTSP), Cet. II. Jakarta: Kencana Prenada Media Group. 